\title{
$\mathrm{u}-\mathrm{WBAN}$ 기반의 센서를 이용한 자세교정 시스템 \\ 설계 및 구현
}

\section{The Design and Implementation of the Position Calibration System Using Sensor on $\mathrm{u}-\mathrm{WBAN}$}

\author{
문승진 ${ }^{*}$ 박윤성 ** \\ Seung-Jin Moon and Yoon-Sung Park \\ * 수원대학교 컴퓨터학과 \\ ** 수원대학교 컴퓨터학과
}

\begin{abstract}
요 약
현대를 살아가는 현대인들이 경험하는 만성통증 및 디스크는 성인의 $80 \%$ 이상이 경험하는 흔한 질병이다. 이러한 질환들 중 교통사고, 추락 등 물리적인 충격에 의한 발생율은 $10 \%$ 정도이며 대부분이 습관적으로 부적합한 자세를 취하게 되어 특 정 부위에 지속적인 스트레스가 쌓여 발생하게 된다. 이처럼 부적합한 자세가 오랫동안 이어져 질환의 원인이 되는 것을 알면서도 고쳐지지 않는 이유는 지속적인 반복을 통한 습관화로 인하여 부적합한 자세를 바로 인지하지 못함으로써 바르 게 교정하지 못하고 지속되어지기 때문이다. 따라서 본 시스템은 자세를 측정할 수 있는 센서들을 사용자에게 부착 후 사 용자의 자세에 따른 데이터를 수집하여 정확한 자세를 측정하고 자세추정알고리즘을 이용하여 해당 자세의 적합여부를 추 정한다. 사용자가 부적합한 자세를 지속적으로 취할 경우 이를 인지할 수 있도록 한다. 그리고 적합한 자세로 변경하도록 유도하여 부적합한 자세의 습관화를 방지하는데 목적을 두고 있다. 또한 부적합한 자세의 원인을 분석 후 제거하여 적합한 자세를 취하는데 보조자의 기능을 수행 한다. 정확한 측정을 통한 반복적인 인지 학습을 통해 올바른 자세를 습관화 한다 면 성장기 어린이와 만성 질환자에게 많은 도움을 줄 것으로 생각 된다.
\end{abstract}

키워드 : 유헬스케어, 유비쿼터스센서네트워크, 상황인지, 바이오센서네트워크

\begin{abstract}
Chronic pain and herniated disk is a common disease that $80 \%$ of adults are experienced. There diseases rates of caused by the physical shock, such as the traffic accident, and the accidental fall is about 10\%. And the most of these diseases is caused by having habitual incorrect position. People know that incorrect position would cause to accumulate continuous stress, but it is not easy to correct position. Because it does not recognize incorrect position repeated habitual consequently. This system collects data of user position after sensors that could measure position attach on use and presumes correct position used by position presumption algorithms. Its system purpose is continuing incorrect position could be aware to user and lead to change to correct position to prevent habituation of incorrect position. If habitual of correct position continues through accurate measurement and repeating cognitive learning, it would help for children and chronic patience.
\end{abstract}

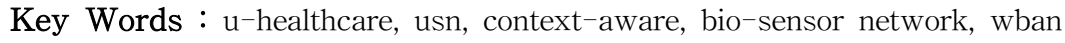

\section{1. 서 론}

의자에 앉거나 서있을 경우 머리와 목, 허리가 일직선이 되어야 한다. 귀와 어깨 옆선이 맞아 떨어져야 바른 자세이 다. 거북이처럼 목을 앞으로 기울이는 자세는 목 디스크를, 의자에 눕는 듯 길게 앉는 자세는 허리 디스크를 유발한다.

접수일자 : 2009년 12월 12일

완료일자 : 2010년 3월 6일

감사의 글 : 본 연구는 경기도의 경기도지역협력연구 센터사업의 일환으로 수행하였음 -

[GRRC 수원2009-B6, u-City 보안감시 기술협력센터]
특히나 한쪽 다리를 꼬아 앉는 자세는 척추를 뒤틀리게 하 는 가증 큰 원인이 되므로 의식적으로 주의를 기울여 앉아 야 하는데 대부분 그러하지 못하고 있다.

특히 책상에 앉아서 컴퓨터를 하거나 공부를 할 경우 목 과 허리가 굽어지는 경우 가 많은데 이는 시선이 눈높이보 다 낮아 고개를 숙이게 만들어 생기는 경우이다. 또한 걷거 나 설 때 등이 구부정한 자세는 척추에 악영향을 미치는 가 장 나쁜 자세이다. 가슴을 압박하므로 폐를 비롯하여 소화 기에도 좋지 않다. 이처럼 부적합한 자세들을 교정된다면 성장기에 있는 연령층은 성장이 원활하게 잘 되도록 촉진 시킬 수 있으며 뇌세포 활성화를 통해 두뇌발달에 도움이 된다. 압박되어있거나 방해받고 있는 신경계통의 흐름을 원 활히 하여 식용, 정력, 활력 등을 되찾게 해줄 수 있다. 또한 
관절의 퇴행성 변이를 예방하고 유연성을 극대화하여 급작 스러운 상해예방과 균형 잡힌 몸매유지에 도움을 준다. 즉 자세교정은 최소의 노력으로 최대의 효과를 얻을 수 있게 된다. 이처럼 자세교정의 중요성에 따라서 본 시스템은 사 용자의 각 부위에 센서를 부착하여 사용자의 상태를 인지하 여 해당 상태에 가장 적합한 자세를 추정하고 현 자세와 비 교하여 적합, 부적합 여부를 판단한 뒤 사용자에게 인지시 켜 줌으로써 사용자에게 지속적인 교정행위를 취할 수 있도 록 한다. 또한 이력관리를 통해 부적합한 자세가 지속적으 로 발생하는 원인을 분석하여 자세교정에 필요한 사용자 인 지작용 뿐만 아니라 원인을 분석하여 부적합한 자세 유발인 자를 제거할 수 있도록 도움을 주는 것 또한 목표로 한다. 본 논문의 구성은 다음과 같다. 2 장에서는 관련연구를 소개 하고 3장에서는 본 논문에서 제안하는 자세 교정 시스템에 대한 전체적인 설계에 관하여 설명한다. 4장에서는 제안한 시스템의 설계를 구현하여 시스템의 프로토 타입과 실험결 과를 설명한다. 5 장에서는 유효성 검증 및 결과를 도출하고 6장 에서는 드러난 문제점들을 분석하고 향후 연구방향을 제시하면서 논문의 결론을 맺는 것으로 마무리한다.

\section{2. 관련 연구}

\section{1 휴대용 의료기기}

휴대용의료기기는 신체의 상태를 모니터링하는 기기로서 평상시 신체의 이상유무를 주기적으로 체크하여 확인하는 장치를 말한다. 의료 서비스를 받기위해서는 병원 및 요양 기관 그리고 보건소등과 같은 곳에 구비되어있는 의료장비 를 이용하게 되는데 당뇨병과 같이 하루에도 수차례 의료서 비스가 필요한 경우 매번 병원을 방문하여 서비스를 제공 받기에는 시간적으로 제약이 있으며, 간단한 처방을 위해 지속적으로 같은 진료가 반복된다면 경제적으로도 부담이 될 수밖에 없다. 또는 심장병과 같이 일상생활에는 지장이 없으나 심장의 상태를 계속 모니터링 해야 할 경우에도 병 원이나 요양기관의 입원을 통해 실시간으로 체크함에 따라 환자의 삶의 질이 떨어지고 활동 범위가 좁아지며 무엇보다 경제적 손실이 컸다. 따라서 휴대용의료기기는 평상시 자신 의 상태를 지속적으로 모니터링 하여 자신의 건강을 스스로 관리하고 휴대용 의료기기를 핸드폰과 연결하여 문제가 발 생 시 저장된 번호로 $\mathrm{SMS}$ 를 보내거나 해당 병원으로 긴급 상황을 알리는 등 나아가 의료기관과의 연계를 통해 진료 및 치료에 활용되고 있다. 현재까지의 의료기기는 혈당체크 를 위해 환자가 직접 혈액을 채취하여 확인하는 화학적 방 법 뿐 만 아니라 혈압, 심전도, 체온, 체중 등을 측정하는 물 리적인 방법이 이용되어지며 일반인들이 일상생활에서 보 다 휴대하기 쉽도록 시계, 반지, 목걸이, 벨트, 속옷, 양말, 신발, 모자 등과 같은 형태이거나 이것들과 일체화 될 수 있도록 제작되어지고 있다. 앞으로는 $\mu \mathrm{m}$ 단위의 MEMS 기 술을 이용하여 체내에 삽입되어져 언제 어디서나 모니터링 이 가능한 시스템이 개발되어 질 것이다.[1]

\subsection{WBAN (Wireless Body Area Network)}

홈 모바일 헬스 케어 및 웰니스 서비스의 경우 개인의 생 체 신호 및 의료 정보의 측정 및 전송, 분석 및 피드백의 과 정이 필수적으로 포함되는데, 이를 위한 핵심 기술이 $\mathrm{WBAN}$ 기술이다. $\mathrm{WBAN}$ 은 $\mathrm{IEEE}$ 에서 전파도달 거리를
기준으로 하여 인체의 내부 및 외부 약 3 미터 이내에 장착 되어지는 장치들을 무선 네트워크로 연결하여 기기간의 상 호 통신을 하며, 용도에 따라 수 $\mathrm{kbps}$ 수십Mbps를 전송하 는 새로운 전송 방식으로 정의하고 있다. 또한 $\mathrm{WBAN}$ 은 의료용과 비의료용으로 구분되어지는데 인체 내부의 특이 한 전파 특성과 전파에 대한 인체의 안전성이 요구되기 때 문이다. 즉, 인체 내부에는 물과 섬유질, 뼈와 같은 다양한 성분으로 구성되어있어 전파 감쇄가 크기 때문에 손실이 적 은 주파수 대역 선정이 중요하기 때문이다. 또한 인체에 미 치는 영향을 최소화하기 위하여 매우 낮은 값으로 제한된 다. 또한 몸에 부착된 노드간의 네트워크인 Wearable BAN 과 인체 내에 이식되는 이식형 노드간의 네트워크인 Implant BAN으로 분류되어진다.[2]

\section{$2.3 \mathrm{u}$-헬스케어}

최근 소형, 휴대 가능한 다양한 종류의 생체신호 측정 센 서의 출현은 초고속 통신망 인프라의 정비 그리고 고성능 무선 통신 기기의 발전과 맞물려 언제 어디에서든 자신의 건강상태를 모니터링하고 개인화된 건강관리 서비스를 받 을 수 있는 유비쿼터스 헬스케어 또는 $\mathrm{u}^{-}$헬스케어 시대의 도래를 예고하고 있다. $\mathrm{u}^{-}$헬스케어가 완비된 이상적인 환경 에서는 사용자들은 무자각 상태에서 자신의 건강상태를 실 시간 하에 지속적으로 모니터링하고 가장 적절한 시점에 가 장 적절한 조치를 취함으로써 자신의 건강상태를 최상으로 유지하는 것이 가능할 것으로 기대된다. 또한 이러한 이상 적인 $\mathrm{u}^{-}$헬스케어 환경은 향후 도래할 노령화 사회 그리고 웰빙을 추구하는 사회에서는 절실히 요청되는 환경이기도 하다. 산업적으로도 $\mathrm{u}^{-}$헬스케어 분야는 향후 그 시장 규모 가 급격히 증가될 것으로 예측된다. 한국전자통신연구소 네 트워크 경제연구팀에서 조사한 시장전망에 따르면 2010년 $\mathrm{u}^{-}$헬스케어 이용자가 700 만명, 이에 따른 시장규모가 1 조 800 억원에 달할 것으로 전망하고 있다. 미국의 경우, NASA, HP, MIT 등과 VivoMetrix 등에서는 PDA나 착용 식 컴퓨터와의 통신이 가능한 원격 건강진단 시스템과 스마 트 엑세서리를 이용하여 착용형 또는 부착형 생체신호 감지 시스템을 개발하고 있다. 일본의 동경대학 Intelligent Cooperative Lab에서 추진중인 헬스케어 프로젝트인 SELF(Self Environment for Life)시스템은 호흡관련 기관 들의 상태를 측정할 수 있는 기술을 활용하여 재택 모니터 링 시스템을 구축하고 있다.[3][4][5]

\section{3. $\mathrm{U}-\mathrm{WBAN}$ 설계}

\section{1 u-WBAN H/W 설계}

$\mathrm{u}-\mathrm{WBAN}$ 기반에서의 자세교정 시스템은 2 가지의 센서로 나뉘어 데이터를 수집하게 된다.

목의 각도를 측정하여 경추상태를 모니터링 하는 센서, 그리고 양 발의 압력을 측정하여 자세 상태를 모니터링 하 는 센서로 나뉜다. 우선 경추상태모니터링 센서의 경우<그 림 $1>$ 과 같이 휘어지는 각도에 따라 저항의 값이 변하는 가변저항을 이용하여 제작 한다. 머리 뒤 쪽과 목 뒤 쪽으 로 이어지도록 설치를 하고 고개가 숙여지면 각도가 작아지 고 고개를 들수록 각도가 커지도록 제작한다. 또한 자세상 태모니터링센서의 경우에는 <그림 2>와 같이 압력의 변화 에 따라 저항이 변하는 가변저항을 이용하여 제작한다. 

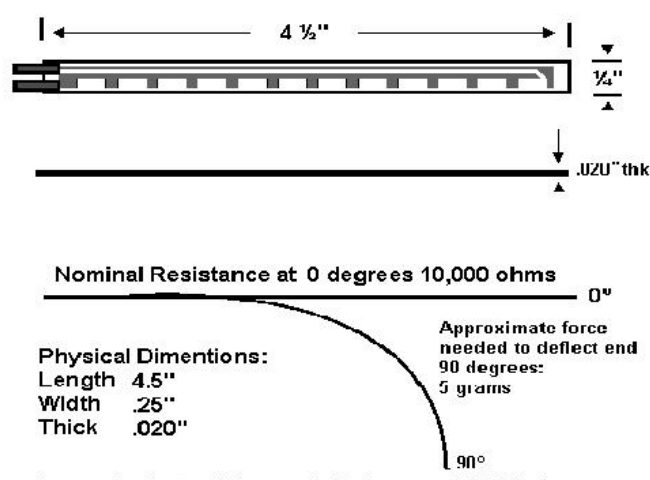

Approximate ResIstance at 90 degrees 35,000 ohms

그림 1. Abrams Gentile flexible 센서

Fig. 1. Abrams Gentile flexible Sensor
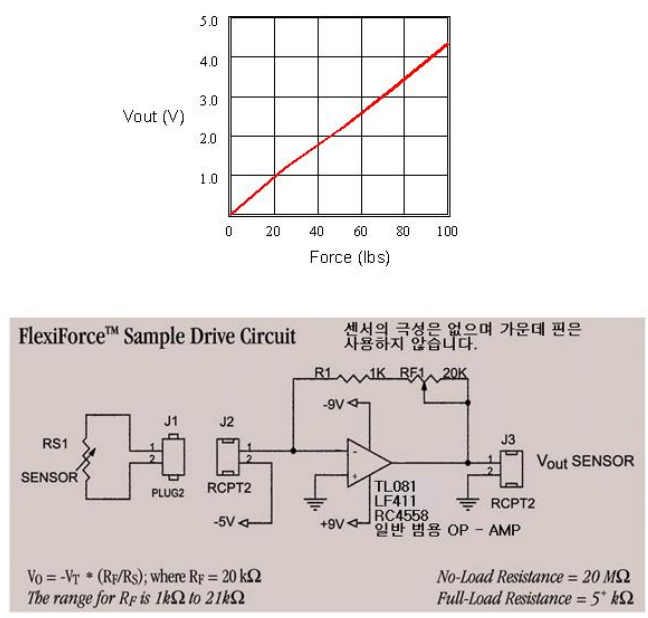

그림 2. TecScan FlexiForce-100 센서

Fig. 2. TecScan FlexiForce-100 Sensor

양발에 체중이 실리는 뒷꿈치나 앞꿈치에 설치한다. 양발 로 서면 전체체중이 실리며 앉으면 다리의 무게만큼 체중이 실리도록 제작한다. 각 센서의 제작 시에는 착용자가 착용 시 이질감이 없도록 하는데 주의가 필요하며 지속적인 데이 터 수집 후에도 변형되지 않아야한다.[6]

\section{$3.2 \mathrm{u}-\mathrm{WBAN} \mathrm{S} / \mathrm{W}$ 설계}

$\mathrm{S} / \mathrm{W}$ 는 자체 제작한 경추상태모니터링센서를 이용하여 사용자 경추의 휘어짐 정도를 측정한다.

머리를 똑바로 세운상태인 귀와 어깨라인이 일직선을 이 루는지, 고개를 푹 숙이고 있는지, 구부정하게 등을 구부리 고 고개만 들고 서있는지 등의 경추상태를 모니터링 할 수 있는 센서를 장착하여 각 자세에 따른 데이터를 수집한다. 또한 자체 제작한 자세상태모니터링센서를 이용하여 사용 자의 자세 상태를 측정한다. 앉아있는지, 서있는지, 적합한 자세로 앉아있는지, 다리를 꼬고 앉아있는지, 의자에서 엉덩 이를 빼고 걸터 앉아 있는지, 한쪽 다리로 서서 기대어 있 는지 등 자세상태를 모니터링 할 수 있는 센서를 장착하여 각 자세에 따른 데이터를 함께 수집한다. 이렇게 수집된 데 이터는 핸드핼드 장비와 게이트웨이로 전송되게 되는데 핸 드핼드 장비는 환자의 기본 상태 값을 데이터베이스로부터
불러온 뒤 적합한 자세의 상태 여부를 인지 할 수 있도록 디스플레이 해주며, 게이트웨이는 각 센서들로부터 수집된 데이터를 데이터베이스에 저장하여 이력관리에 필요한 데 이터를 생성하게 된다. <그림 3>과 같이 사용자가 착용한 센서들은 사용자의 상태를 측정하여 데이터를 송신하고 사 용자의 인지학습에 필요한 디스플레이용 장비와 데이터베 이스로 저장을 위한 게이트웨이는 송신된 데이터를 받아 처 리한다.[7]

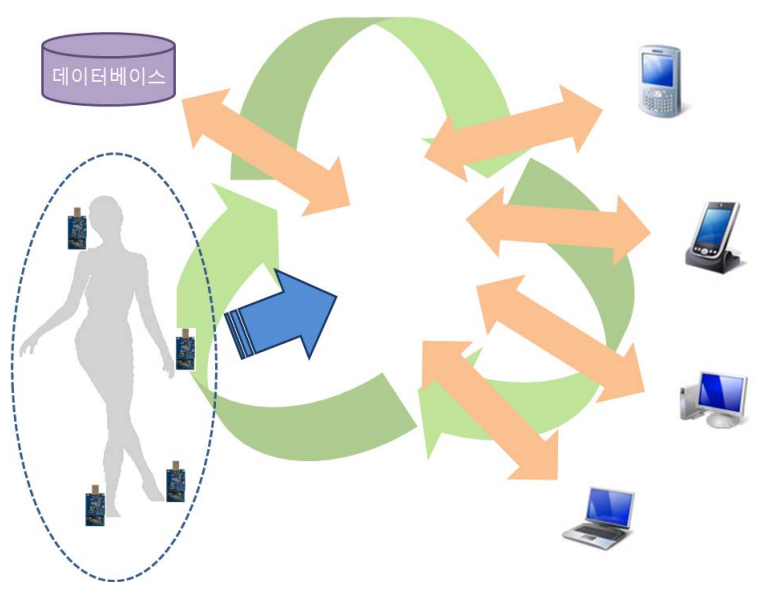

그림 3. 전체 시스템 개요

Fig. 3. Overview of the system

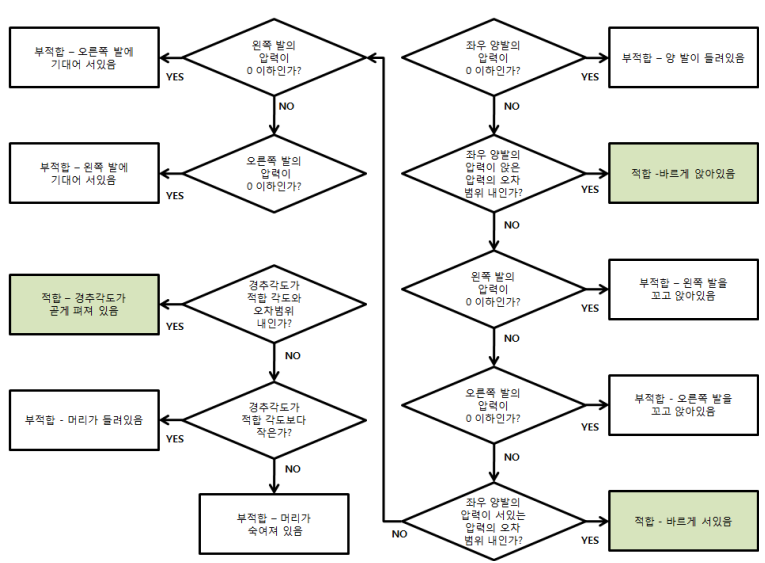

그림 4. 자세 추정 알고리즘

Fig. 4. Estimated position algorithm

각 센서로부터 측정된 데이터를 가지고 자세추정을 하기 위한 알고리즘은 <그림 $4>$ 와 같은 순서에 따라 처리한다.

\section{U-WBAN 구현}

\section{1 하드웨어 구성}

\section{1 .1 센서보드}

센서에서 측정된 물리적인 데이타를 디지털로 변환하여 핸드핼드 장비와 게이트웨이로 송신가능한 데이터 형식으 로 변환하여 송신하는 기능을 한다. 


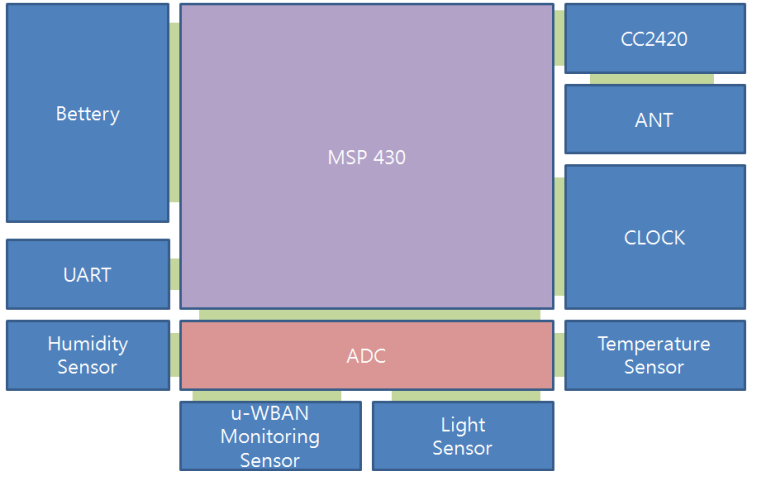

그림 5. 센서보드 블록 다이어그램

Fig. 5. Sensorboard block diagram

WBAN중 Wareable BAN내에서 사용되어지기 때문에 신체에 미치는 영향은 고려하지 않았다. 또한 아직 $\mathrm{WBAN}$ 의 PHY는 표준화 되어있지 않기 때문에 IEEE 802.15 WPAN기반의 Zigbee와 Bluetooth중 저전력을 위해 Zigbee 를 송수신 방식으로 채택하였다. 센서보드의 구성도는 <그 림 $5>$ 과 같다.

\section{$4.1 .2 \mathrm{u}-\mathrm{WBAN}$ 모니터링 시스템 센서}

경추의 상태를 모니터링하기위해서는 유연한 강도를 가 지며 착용감이 좋아야한다. 경추의 상태는 휘어지는 정도에 따라 민감한 측위가 가능해야하며 같은 센서라도 장착 부위 에 따라 측정값이 달라 적합한 위치를 선정하는데 많은 어 려움이 따른다. 따라서 본 연구를 통한 경추 측위를 측정하 기위해서 <그림 6>과 같은 센서를 개발하였다.

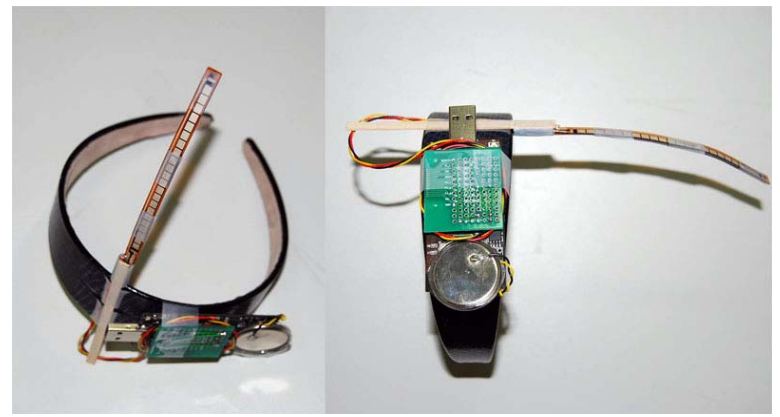

그림 6. 경추상태모니터링센서

Fig. 6. Cervical condition monitoring sensor

경추의 각도를 측정하기 위해서는 어깨와 머리 뒷부분과 의 각도를 측정해야하는데 목 부분에 고정을 할 경우 착용 감이 좋지 않고 고정시킬 경우 목의 움직임에 민감히 반응 하여 정확한 측위가 불가능하였다. 따라서 머리 뒷부분에 고정을 하고 <그림 $6>$ 와 같이 휘어짐 정도를 측정 가능한 센서를 장착한 후 약 15 도 정도의 값을 유지할 수 있도록 받침대를 삽입하여 경추의 펴짐, 구부러짐, 젖혀짐 등을 측 정 가능하도록 하였다. 사용자의 자세를 추정하기위해서는 두 발 사이에 가해지는 압력을 측정하여 추정한다. 서있을 경우, 앉을 경우, 부적합한 자세인 경우 등 자세를 유지하기 위해서는 두발이 지면에 닿아 있게 된다. 서있을 경우에는 체중이 절반씩 나뉘어 양발에 분산되어지며 앉아있을 경우 에도 다리의 무게만큼씩 하중을 싣기 때문에 서있는 경우와
앉은 경우 그리고 다리를 꼬고 앉거나 한쪽발에 기대어 서 있는 경우에 각 자세에 따른 추정이 가능하다.

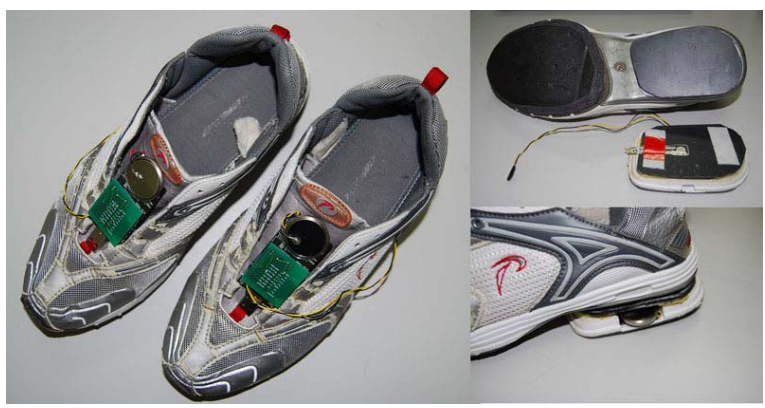

그림 7. 자세상태모니터링센서

Fig. 7. Stance monitoring sensor

<그림 4>에 따라 양발에 고른 압력이 분포된다면 적합 하게 앉거나 서있는 자세이며 한쪽 발이나 양발에 압력이 가해지지 않는다면 부적합한 자세로 판정을 하게 된다. 따 라서 체중이 실리는 앞꿈치와 뒷꿈치에 <그림 2>와 같은 압력 센서를 부착하였다. 체중이 발 전체로 분산되지만 체 중을 측정하기 위함이 아닌 자세 추정을 위한 측정이므로 하중 없음, 앉을 때 하중 그리고 서 있을 때 하중의 측위가 가능한 범위내로 설정하였다. <그림 7>과 같이 센서는 신 발의 중창 부분에 삽입하고 센서보드는 뒤축 중창에 삽입 또는 발등 위에 장착 가능하도록 구성하였다.

\section{$4.2 \mathrm{u}-\mathrm{WBAN}$ 모니터링 시스템}

\subsection{1 개발 소프트웨어}

자세교정시스템을 구성하는 프로그램은 <그림 8>과 같 다. 좌측 상단에는 사용자의 상태를 한눈에 알아 볼 수 있 도록 <그림 $9>$ 과 같은 이미지를 통해 현재의 환자상태를 보여준다.

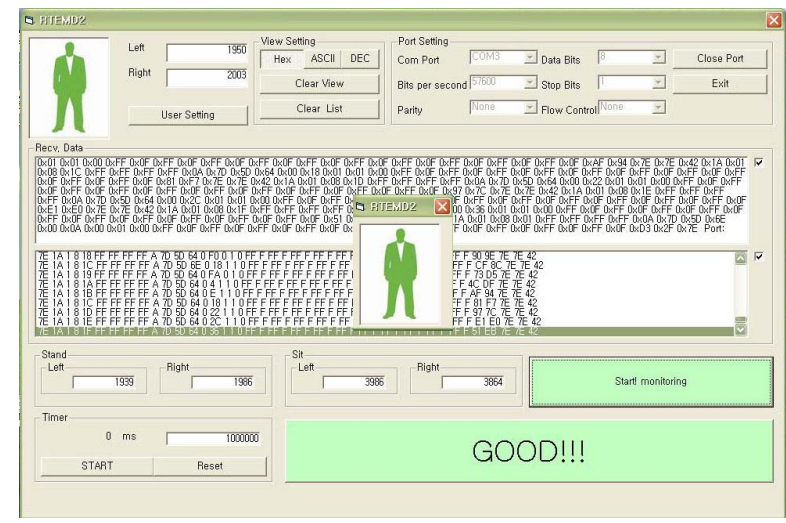

그림 8. 소프트웨어 프로그램

Fig. 8. Software program

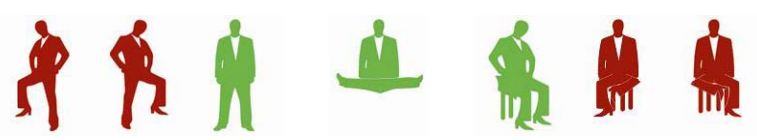

그림 9. 사용자자세추정결과 아이콘

Fig. 9. Icons of estimated user position result

알기 쉽고 이해하기 쉽게 단순한 디자인을 통해 즉각적 
인 인지가 가능하도록 하였다. 또한 우측 상단에는 게이트 웨이와의 접속을 위한 컨트롤들이 구성되어 있으며 중간에 는 수신되는 데이터의 패킷들을 보여준다. 또한 하단에는 수신되는 각 센서들의 송신 데이터 중 센서 값만을 추출하 여 보여주고 있다. 수신되는 데이터들은 설정된 주기 간격 으로 데이터베이스에 저장되어지며 부적합 자세로 판정되 면 소리알람을 통하여 사용자에게 인지시켜 준다.

또한 <그림 8>처럼 최소화시킬 경우 이미지 정보만을 제공하여 다른 작업 중에도 지속적인 인지학습이 이루어 질 수 있도록 하였다.

\section{5. 유효성 검증 및 결과}

표 1. 자세에 따른 경추상태모니터링센서 측정 결과

Table 1. The result of cervical condition accordance with position

\begin{tabular}{|c|c|c|r|r|}
\hline $\begin{array}{c}\text { 사용자 } \\
\text { 착용 후 자세 }\end{array}$ & $\begin{array}{c}\text { 측정 } \\
\text { 횟수 }\end{array}$ & 평균값 & 표준편차 & 인식율 \\
\hline 정상 & 100 & 472.3 & 10.3 & $98 \%$ \\
\hline 숙임 & 100 & 496.6 & 0.1 & $100 \%$ \\
\hline 젖힘 & 100 & 425.8 & 16.8 & $96 \%$ \\
\hline
\end{tabular}

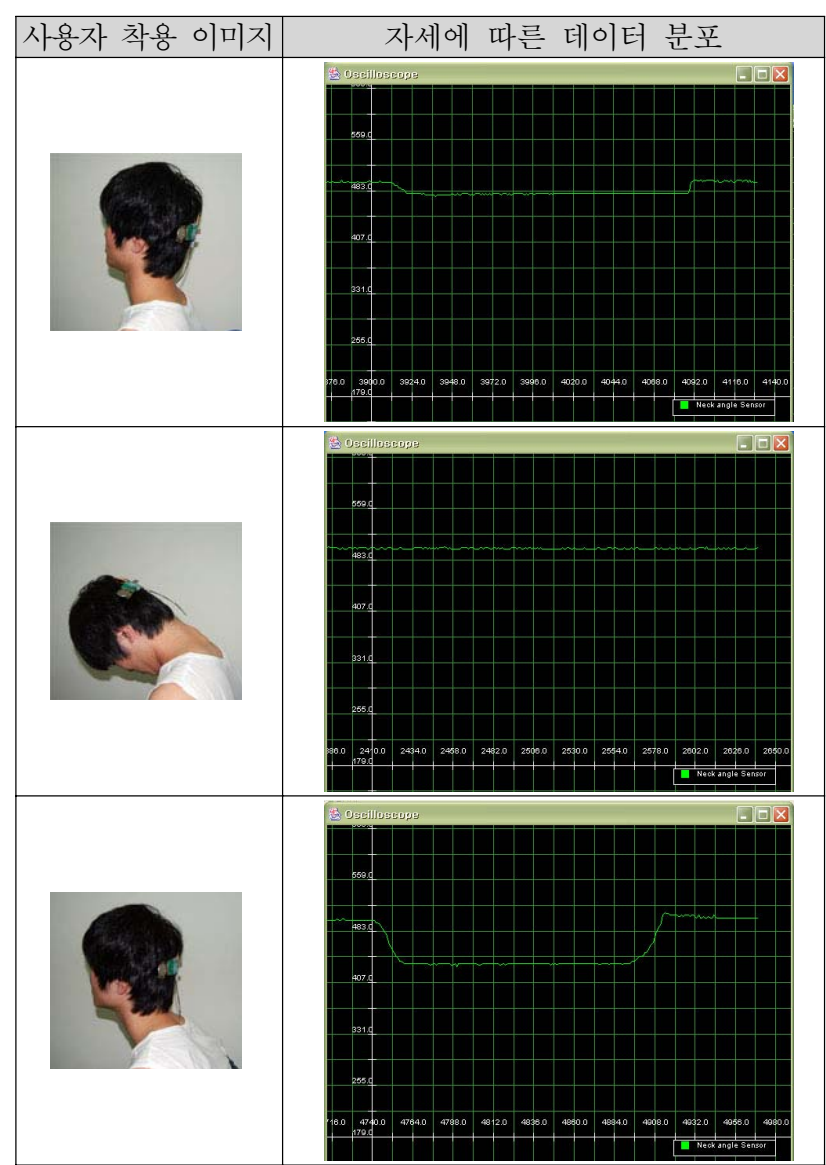

그림 10. 자세에 따른 경추상태모니터링센서 데이터 분포 그래프

Fig. 10. The graph of cervical condition accordance with position

본 연구의 유효성을 검증하기위해 실험체를 이용하여 3
개월간 데이터를 측정하였다. 사용자에 따른 다향성에 적용 가능하게 하기위해서 구동 전 설정 시에 각 자세별 데이터 를 10 번식 측정하여 평균과 이의 표준 편차 값을 적용하여 자세별 추정 범위를 설정하게 된다. 따라서는 절대 값이 아 닌 상대 값으로 설정되기 때문에 가벼운 여성이나 무거운 남성일 경우에도 같은 알고리즘으로 처리가 가능하다. 경추 상태모니터링센서는 사용자가 착용 시 <그림 10>와 같은 결과 값을 보여준다.

표 2. 자세에 따른 자세상태모니터링센서 측정 결과

Table 2. The result of Stance condition accordance with position

\begin{tabular}{|c|c|c|c|c|c|c|}
\hline $\begin{array}{c}\text { 사용자 } \\
\text { 착용 후 자세 }\end{array}$ & $\begin{array}{l}\text { 측정 } \\
\text { 횟수 }\end{array}$ & \multicolumn{2}{|c|}{ 평균값 } & \multicolumn{2}{|c|}{ 표준편차 } & 인식율 \\
\hline \multirow{2}{*}{ 바르게 선 자세 } & \multirow{2}{*}{100} & $\mathrm{R}$ & 1989.3 & $\mathrm{R}$ & 214.7 & \multirow{2}{*}{$97 \%$} \\
\hline & & $\mathrm{L}$ & 1863.6 & $\mathrm{~L}$ & 186.8 & \\
\hline \multirow{2}{*}{$\begin{array}{c}\text { 오른발로 } \\
\text { 기대어 선 자세 }\end{array}$} & \multirow{2}{*}{100} & $\mathrm{R}$ & 1202.7 & $\mathrm{R}$ & 221.2 & \multirow{2}{*}{$99 \%$} \\
\hline & & $\mathrm{L}$ & 4095.0 & $\mathrm{~L}$ & 0 & \\
\hline \multirow{2}{*}{$\begin{array}{c}\text { 왼발로 기대어 } \\
\text { 선 자세 }\end{array}$} & \multirow{2}{*}{100} & $\mathrm{R}$ & 4095.0 & $\mathrm{R}$ & 0 & \multirow{2}{*}{$98 \%$} \\
\hline & & $\mathrm{L}$ & 1263.8 & $\mathrm{~L}$ & 284.4 & \\
\hline \multirow{2}{*}{$\begin{array}{c}\text { 바르게 앉은 } \\
\text { 자세 }\end{array}$} & \multirow{2}{*}{100} & $\mathrm{R}$ & 3982.2 & $\mathrm{R}$ & 33.3 & \multirow{2}{*}{$98 \%$} \\
\hline & & $\mathrm{L}$ & 3998.2 & $\mathrm{~L}$ & 25.5 & \\
\hline \multirow{2}{*}{$\begin{array}{c}\text { 오른발을 } \\
\text { 꼬고앉은 자세 }\end{array}$} & \multirow{2}{*}{100} & $\mathrm{R}$ & 4095.0 & $\mathrm{R}$ & 0 & \multirow{2}{*}{$91 \%$} \\
\hline & & $\mathrm{L}$ & 3230.6 & $\mathrm{~L}$ & 585.5 & \\
\hline \multirow{2}{*}{$\begin{array}{l}\text { 왼발을 꼬고 } \\
\text { 앉은 자세 }\end{array}$} & \multirow{2}{*}{100} & $\mathrm{R}$ & 3562.5 & $\mathrm{R}$ & 392.6 & \multirow{2}{*}{$89 \%$} \\
\hline & & $\mathrm{L}$ & 4095.0 & $\mathrm{~L}$ & 0 & \\
\hline \multirow{2}{*}{$\begin{array}{l}\text { 엉덩이를 배고 } \\
\text { 걸터 앉은 자세 }\end{array}$} & \multirow{2}{*}{100} & $\mathrm{R}$ & 4095.0 & $\mathrm{R}$ & 0 & \multirow{2}{*}{$100 \%$} \\
\hline & & $\mathrm{L}$ & 4095.0 & $\mathrm{~L}$ & 0 & \\
\hline
\end{tabular}

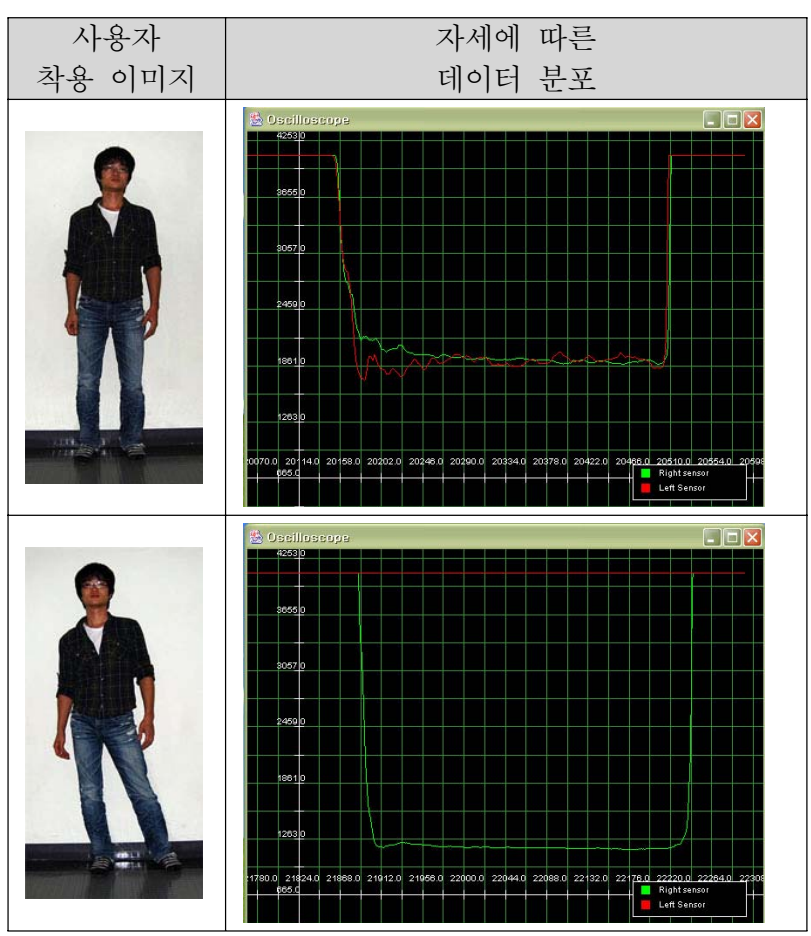

그림 11. 자세에 따른 자세상태모니터링센서 데이터 분포 그래프

Fig. 11. The graph of Stance condition accordance with position

좌측에는 사용자가 착용 후 자세에 따른 경추의 각도를 
보여주며 우측에는 사용자가 착용한 경추상태모니터링센서 로부터 데이터를 전달받아 저장 후 현재 상태를 실시간으로 모니터링 하여 보여주고 있다. 숙인 경우는 고정 값 이므로 편차가 거의 없지만 곧은 자세나 젖힌 자세의 경우에는 측 정시마다 값이 다르기 때문에 편차가 발생하였다. 미세한 움직임에 오동작을 방지하기 위해서는 충분한 허용 범위 설 정이 필요하다.

<표 1>에 따르면 정상일 경우의 값의 평균이 472.3 이고 숙인경우가 496.6 젖힌 경우가 425.8 이므로 적합판정을 위 한 허용범위는 적합 평균값을 기준으로 \pm 표준편차 값을 적 용하고 부적합 판정을 위한 허용범위는 각 측정값 \pm 표준편 차 값을 적용한다. 허용범위 적용 후 인식율은 정상일 경우 $98 \%$, 숙일 경우 $100 \%$, 젖힐 경우 $96 \%$ 로 전체 평균 $98 \%$ 의 인식율을 보여준다.

표 3. 인지학습기능을 끈 상태로 1 달간의 일평균 데이터

Table 3. The average one months data (did not use system)

\begin{tabular}{|c|c|c|c|c|c|c|c|c|c|}
\hline 단위 : 횟수/시간 & $\begin{array}{l}0 \\
\sim_{1}\end{array}$ & \begin{tabular}{|l|}
1 \\
$\sim$
\end{tabular} & \begin{tabular}{l|l}
2 \\
$\sim 3$
\end{tabular} & \begin{tabular}{l|}
3 \\
$\sim 4$
\end{tabular} & \begin{tabular}{l|l}
4 \\
$\sim 5$
\end{tabular} & $\begin{array}{l}5 \\
\sim 6\end{array}$ & $\begin{array}{l}6 \\
\sim 7\end{array}$ & $\begin{array}{l}7 \\
\sim 8\end{array}$ & $\begin{array}{l}\text { 평 } \\
\text { 균 }\end{array}$ \\
\hline $\begin{array}{c}\text { 엉덩이 빼고 앉은 } \\
\text { 자세 }\end{array}$ & 13 & 10 & 21 & 11 & 8 & 6 & 15 & 21 & 13 \\
\hline $\begin{array}{l}\text { 왼쪽다리 꼬고 } \\
\text { 앉은 자세 }\end{array}$ & 2 & 3 & 3 & 2 & 1 & 2 & 2 & 2 & 2 \\
\hline $\begin{array}{c}\text { 오른쪽다리 꼬고 } \\
\text { 앉은 자세 }\end{array}$ & 8 & 9 & 9 & 13 & 16 & 9 & 7 & 5 & 10 \\
\hline $\begin{array}{c}\text { 왼쪽다리로 기대 } \\
\text { 선 자세 }\end{array}$ & 1 & 0 & 1 & 0 & 1 & 2 & 1 & 2 & 1 \\
\hline $\begin{array}{l}\text { 오른쪽다리로 } \\
\text { 기대 선 자세 }\end{array}$ & 0 & 0 & 1 & 0 & 0 & 0 & 2 & 1 & 1 \\
\hline 고개 숙인 자세 & 1 & 2 & 1 & 1 & 2 & 2 & 3 & 1 & 2 \\
\hline 고개 젖힌 자세 & 11 & 15 & 13 & 11 & 8 & 17 & 19 & 16 & 14 \\
\hline 부적합 누적 회수 & 36 & 39 & 49 & 38 & 36 & 38 & 49 & 48 & 42 \\
\hline
\end{tabular}

자세상태모니터링센서는 좌,우 양발에 장착되어져 있으 며 다리를 꼬고 앉거나 한쪽 발에 기대어 설 경우 한쪽발에 는 압력이 실리지 않는 점을 이용하고 앉은 상태와 선자세 의 발바닥에 실리는 압력의 차이를 이용하여 자세를 추정하 게 된다.

하중을 받게 되는 압력센서는 앞꿈치와 뒷꿈치 2 곳에 설 치되지만 자세추정을 위해서는 뒷꿈치 쪽의 센서의 데이터 만을 사용하게 된다. 가슴을 펴고 바르게 서는 경우 체중이 대부분 뒷꿈치 쪽에 실리게 되며 바르게 앉은 자세에서도 다리의 무게만큼의 하중은 발 뒷꿈치 쪽으로 실리게 된다. 따라서 앞꿈치 쪽의 센서는 제거되어도 자세상태모니터링 을 하는데 무리가 없었다. <표 2>에 따르면 경추상태모니 터링 센서와 마찬가지로 각 자세에 다른 평균값을 산출한 뒤 \pm 표준편자 만큼의 값을 허용범위로 주어진 뒤 전체 자세 별 인식율을 측정한 결과 $96 \%$ 의 결과를 보여주었다.
표 4. 인지학습기능을 켠 상태로 1 달간의 일평균 데이터

Table 4. The average one months data (used system)

\begin{tabular}{|c|l|l|l|l|l|l|l|l|l|}
\hline 단위 : 횟수/시간 & 0 & 1 & 2 & 3 & 4 & 5 & 6 & 7 & 평 \\
\hline $\begin{array}{c}\text { 엉덩이 빼고 앉은 } \\
\text { 자세 }\end{array}$ & 9 & 11 & 10 & 21 & 13 & 11 & 15 & 7 & 12 \\
\hline $\begin{array}{c}\text { 왼쪽다리 꼬고 } \\
\text { 앉은 자세 }\end{array}$ & 2 & 3 & 3 & 2 & 0 & 0 & 1 & 2 & 2 \\
\hline $\begin{array}{c}\text { 오른쪽다리 고고 } \\
\text { 앉은 자세 }\end{array}$ & 10 & 10 & 6 & 11 & 10 & 18 & 10 & 9 & 11 \\
\hline $\begin{array}{c}\text { 왼쪽다리로 기대 } \\
\text { 선 자세 }\end{array}$ & 0 & 0 & 0 & 1 & 0 & 0 & 2 & 0 & 0 \\
\hline $\begin{array}{c}\text { 오른쪽다리로 } \\
\text { 기대 선 자세 }\end{array}$ & 0 & 0 & 1 & 0 & 0 & 0 & 1 & 1 & 0 \\
\hline $\begin{array}{c}\text { 고개 숙인 자세 } \\
\text { 고개 젖힌 자세 }\end{array}$ & 1 & 2 & 1 & 1 & 2 & 2 & 3 & 1 & 2 \\
\hline 부적합 누적 회수 & 32 & 41 & 32 & 47 & 34 & 46 & 43 & 33 & 39 \\
\hline
\end{tabular}

표 5. 부적합자세 유발 원인을 제거한 후 1 달간의 일평균 데이터

Table 5. The average one months data (removed cause)

\begin{tabular}{|c|c|c|c|c|c|c|c|c|c|}
\hline 단위: 횟수/시간 & $\begin{array}{l}0 \\
\sim 1 \\
\end{array}$ & $\begin{array}{l}1 \\
\sim 2 \\
\end{array}$ & $\begin{array}{l}2 \\
\sim 3 \\
\end{array}$ & $\begin{array}{l}3 \\
\sim 4 \\
\end{array}$ & $\begin{array}{l}4 \\
\sim 5 \\
\end{array}$ & $\begin{array}{l}5 \\
\sim 6 \\
\end{array}$ & $\begin{array}{l}6 \\
\sim 7 \\
\end{array}$ & $\begin{array}{l}7 \\
\sim 8 \\
\end{array}$ & $\begin{array}{l}\text { 평 } \\
\text { 균 }\end{array}$ \\
\hline $\begin{array}{c}\text { 엉덩이 빼고 앉은 } \\
\text { 자세 }\end{array}$ & 5 & 8 & 5 & 6 & 3 & 3 & 5 & 7 & 5 \\
\hline $\begin{array}{c}\text { 왼쪽다리 꼬고 } \\
\text { 앉은 자세 }\end{array}$ & 2 & 3 & 3 & 2 & 1 & 2 & 2 & 2 & 2 \\
\hline $\begin{array}{c}\text { 오른쪽다리 꼬고 } \\
\text { 앉은 자세 }\end{array}$ & 4 & 4 & 2 & 2 & 4 & 2 & 1 & 4 & 3 \\
\hline $\begin{array}{c}\text { 왼쪽다리로 기대 } \\
\text { 선 자세 }\end{array}$ & 1 & 0 & 1 & 0 & 1 & 2 & 1 & 2 & 1 \\
\hline $\begin{array}{c}\text { 오른쪽다리로 기대 } \\
\text { 선 자세 }\end{array}$ & 0 & 0 & 0 & 1 & 0 & 0 & 2 & 1 & 1 \\
\hline 고개 숙인 자세 & 1 & 2 & 1 & 1 & 2 & 2 & 3 & 1 & 2 \\
\hline 고개 젖힌 자세 & 5 & 2 & 2 & 3 & 1 & 5 & 1 & 3 & 3 \\
\hline 부적합 누적 회수 & 18 & 19 & 14 & 15 & 12 & 16 & 15 & 20 & 16 \\
\hline
\end{tabular}

<그림 11>은 해당 자세별 압력데이타의 분포를 그래프 로 보여주고 있다. 개발된 프로그램을 이용하여 1달간(20 일) 1 일 8 시간씩 착용하고 상태를 모니터링 하였다. 핸드핼 드 장비를 이용하여 이동 중 이나 고정자세 에서도 데이터 를 지속적으로 측정 저장하였다. 부득이하게 신발을 벗어야 할 경우에는 해당 시간동안 데이터를 측정하지 않고 평균 산출값에 반영하지 않았다. 자세교정시스템의 효과를 확인 하기위하여 처음 1 달은 인지학습기능을 끈 상태로 부적합 
한 상태가 지속되더라도 사용자가 인지할 수 없는 상태에서 측정하였으며 다음 1 달은 인지학습기능을 켠 상태로 부적 합한 상태가 지속되면 바로 사용자에게 인지시켜 적합한 자 세로 변경을 유도하였다. 그리고 그다음 1 달간은 2 달간의 데이터를 통해 부적합한 자세를 유발하는 원인을 분석하여 조치를 취한 뒤 다시 1 달간 데이터를 측정 하였다. <표 3> 은 인지학습기능이 꺼진 상태로 1 달간 기록된 데이터의 일 평균을 그래프화 하였으며 <표 $4>$ 는 인지학습기능을 켠 상 태로 1 달간 기록된 데이터의 일평균을 보여준다. <표 $3>$ 과 <표 4>의 평균 횟수를 보면 자세교정시스템 적용 후에 부 적합한 자세의 횟수는 크게 개선되지 않았으나 <표 6>의 자료에 따르면 부적합 자세의 누적시간은 현격하게 줄어든 점을 알 수 있다. 또한 두 그래프의 분석 결과 앉아 있는 경 우 지속적으로 엉덩이를 빼고 걸터앉는 자세의 횟수가 많고 앉은 상태에서의 경추상태가 부적합한 경우가 많았다. 이에 허리를 받쳐주는 의자로 변경하고 모니터의 높이를 눈높이 로 올린 뒤 노트북 사용 시 에도 받침대를 사용하여 눈높이 와 일치시킨 후 다시 1 달간 데이터를 측정 하였다.

표 6. 부적합자세 월 단위 시간별 평균 누적 시간 데이터 Table 6. Cumulative hours of data (not suitable position)

\begin{tabular}{|c|r|r|r|r|r|r|r|r|r|}
\hline 단위: & 0 & 1 & 2 & 3 & 4 & 5 & 6 & 7 & 평 \\
분/시간 & $\sim_{1}$ & $\sim_{2}$ & $\sim_{3}$ & $\sim 4$ & 5 & $\sim 6$ & 7 & $\sim 8$ & 균 \\
\hline 1개월 & 38 & 25 & 20 & 19 & 50 & 25 & 33 & 18 & 29 \\
\hline 2개월 & 11 & 14 & 11 & 16 & 11 & 15 & 14 & 11 & 13 \\
\hline 3개월 & 6 & 6 & 5 & 5 & 4 & 5 & 5 & 7 & 5 \\
\hline
\end{tabular}

<표 5>는 부적합한 자세 유발 원인을 제거한 뒤 기록된 데이터의 일평균의 데이터이다. 처음 1 달간의 일평균 데이 터와 비교할 경우 부적합 자세 횟수와 누적 시간이 함께 줄 어든 것을 알 수 있다.

\section{6. 결론 및 향후 연구방향}

자세교정시스템을 착용 전의 결과를 보면 하루 동안 시 간당 평균 42회 이상의 부적합한 자세를 취하며 시간당 29 분 동안 해당 자세를 유지하게 된다. 하지만 자세교정시스 템을 착용 후 부적합한 자세를 취하는 횟수는 평균 39회로 큰 차이를 보이지 않았지만 부적합한 자세를 취하고 있는 시간은 13 분으로 약 $55.1 \%$ 이상 감소되었음을 알 수 있었다. 또한 엉덩이를 빼고 앉은 자세, 오른쪽 다리를 꼬고 앉은 자세, 고개 젖힌 자세에서 많은 부적합자세를 유지하였다. 따라서 지속적인 부적합한 자세는 컴퓨터 의자의 불편함과 모니터 높이의 문제로 판단하고 모니터의 높이를 올리고 노 트북 받침대를 설치함으로서 부적합 자세 횟수와 시간을 각 각 16 회 5분으로 $61.9 \% 82.7 \%$ 씩 감소시켰다. 3달간의 짧은 기간 동안 측정되었기 때문에 사용자의 습관변경 여부의 적 합성 및 측정은 이루어지지 않았다. 앞으로 1 년 이상의 지 속적인 착용을 통해 부적합 자세를 지속적으로 인지하여 적 합한 자세를 취하도록 하여 사용자의 습관 변화에 대한 연 구가 지속적으로 필요할 것이며 발 앞꿈치에 장착된 압력센 서를 이용하여 자세의 상태를 모니터링 할 뿐만 아니라 걸 음걸이의 패턴을 인지하여 부적합한 걸음걸이를 교정할 수 있도록 지속적인 연구 개발이 이루어 져야 할 것이다.

\section{참 고 문 헌}

[1] 김홍규, 문승진, " $\mathrm{u}$-EMS : 바이오 센서 네트워크 기반의 응급 구조 시스템" 정보과학회논문지 : 컴 퓨팅의 실제 및 레터 제13권, 7호 pp. 433-441, 2007. 12

[2] 장병준, 최선웅, “Wireless Body Area Network 기 술 동향”, 한국전자파학회, 제 19 권, 3 호, pp. 37-47, 2008. 12

[3] 한동수, 정명애, "U-Healthcare 국내외 연구 동향 및 서비스 플랫폼”, 정보통신연구진흥원, 주간기술 동향 1246호, 2006. 05

[4] 김희찬, 강재민, “유-헬스케어의 기술 현황과 전 망”, 정보과학회지 제26권, 1호, pp. 38-45, 2008. 1

[5] 심동희, "USN 기반 원격건강모니터링시스템 설 계”, 한국정보기술학회논문지 제7권, 4호, $\mathrm{pp}$. 183-187, 2009. 8

[6] http://www.tekscan.com/

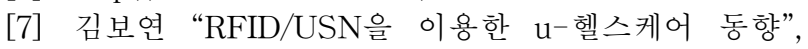
정보처리학회지, 제 15 권, 1호, pp. 14-25, 2008. 1

\section{저 자 소 개}

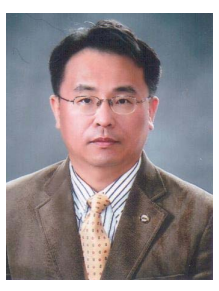

문승진 (Seung-Jin Moon)

1986년 : 미 텍사스 주립대 컴퓨터학과 학사 졸업

1991년:미 플로리다 주립대 컴퓨터학과 석사 졸업

1997년:미 플로리다 주립대 컴퓨터학과 박사 졸업

1997년 현재 : 수원대학교 컴퓨터학과 부교수

관심분야 : 실시간 임베디드 시스템, 실시간 센서 네트워크 시스템, 실시간 데이터베이스

Phone : 031-220-2610

Fax : 031-229-8281

E-mail : sjmoon@suwon.ac.kr

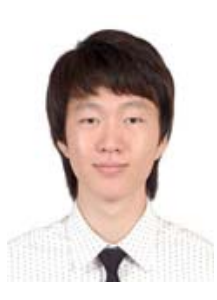

박윤성 (Yoon-Sung Park)

2008년 : 수원대 컴퓨터학과 졸업

2010년 : 수원대 컴퓨터학과 석사 졸업.

2010년 현재 : (주)쎄미시스코

관심분야 : 임베디드 시스템, 실시간 위치추적

Phone : 010-2298-8942

Fax

E-mail :yspak82@suwon.ac.kr 